\title{
Ingestive behaviour and performance of feedlot lambs fed saccharine sorghum and corn silages
}

\author{
F.M. Vargas Juniori", K. Cansian², H.L. Pereira', M.L. Longo ${ }^{3}$, A.C. Valério1, M.A.P. Orrico \\ Junior ${ }^{1}$, M. Retore ${ }^{4}$, A.B.R. Siqueira ${ }^{1} \&$ T. Fernandes ${ }^{1}$ \\ ${ }^{1}$ Faculty of Agricultural Sciences, Federal University of Grande Dourados, Rodovia Dourados-Itahum, km 12, Caixa \\ Postal, 322, Dourados, MS, 79825-070 \\ ${ }^{2}$ Federal University of Mato Grosso do Sul (FAMEZ) Caixa Postal 549. CEP 79070-900. Campo Grande - MS - Brazil. \\ ${ }^{3}$ State University of West Paraná, Rua Pernambuco, 1777 - Centro - cep: 85960-000 Marechal Cândido Rondon - PR - \\ Brazil. \\ ${ }^{4}$ Embrapa Agricultural West- Rodovia BR 163, Km 253,6 - Cx. Postal 449. CEP 79804 - 970 - Zona Rural, Dourados - \\ MS, Brazil.
}

(Submitted 4 January 2020; Accepted 19 January 2020; First published online 25 April 2020)

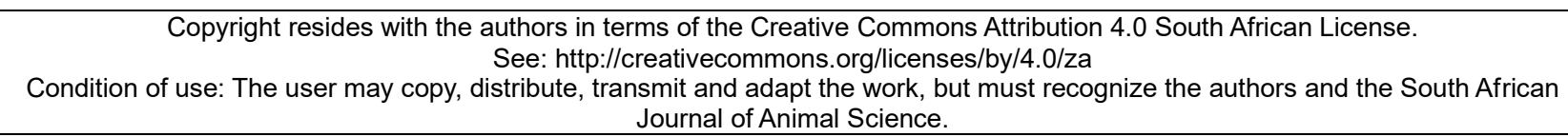
Journal of Animal Science.

\begin{abstract}
This study evaluated the ingestive behaviour and performance of feedlot lambs fed saccharine sorghum and corn silages. Ten animals were randomly selected from a group of 32 uncastrated male Suffolk lambs. The four treatments consisted of diets with $50 \%$ of silage made from forage sorghum (BD 1615), two varieties of saccharine sorghum (BRS 506 and BRS 511), and corn (BRS 2223). Ingestive behaviour was observed by a scan sampling method using seven strategically positioned video cameras so as not to interfere with the usual animal behaviour. The animals were observed for three 48-hour periods at 15-day intervals, with a total of 144 hours of observation. Video recordings were then examined to identify the time spent in ruminating, eating, drinking water and idling. Times spent feeding or drinking water were not significantly affected by the treatments. Animals fed forage sorghum silage had higher neutral detergent fibre (NDF) intake ( $0.41 \mathrm{~kg}$ of NDF), thus spent more time ruminating (342 min/day). Rumination time was similar for the BD 1615 and BRS 506 silages and was $85 \mathrm{~min} /$ day greater than for the BRS 511 and BRS 2223 silages, which were similar. Average daily gain was greater for BRS 2223 ( $275 \mathrm{~g} /$ day) than for BRS 506 and BRS 511 silages, which were similar (196 g/day). Ingestive behaviour for BRS 511 was similar to that observed for BRS 2223. Ingestive behaviour for BRS 506 was similar to that observed for BD 1615. Average daily gain was related to intake and ruminating efficiency.
\end{abstract}

Keywords: eating, idling, roughage, rumination, sheep (Ovis aires)

\#Corresponding author E-mail address: fernando.mvargasjr@gmail.com

\section{Introduction}

Because of the need for renewable fuel sources, saccharine sorghum has been widely studied for ethanol production. The National Centre for Research on Corn and Sorghum (CNPMS) produced varieties BRS 506 and BRS 511 to improve saccharine sorghum cultivars that are intended for ethanol production. However, there is little information about their potential as roughage in ruminant feed and as a silage crop (Orrico Junior et al., 2015).

Overall, corn and sorghum crops adapt well to the ensilage process, given their ease of cultivation, high yield, and desirable characteristics for fermentation. These characteristics include adequate dry matter (DM) content, low buffer power, and sufficient soluble carbohydrates, which does away with the need for additives to stimulate fermentation. In addition, sorghum is notable for its ability to withstand moisture deficit conditions and for its usefulness as an energy source for ruminant livestock (Verma et al., 2018).

Although the use of sorghum silage is viable in ruminant feeding, using it as the sole ingredient in a ration for young slaughter animals does not meet the nutritional requirements for growth. Thus, concentrate supplementation becomes crucial for animal finishing to produce standardized carcasses and to attain quality meat for consumers. 
Feed intake is a physiological phenomenon that integrates the animal's ability to deal with changes in diet composition and metabolic demands. Understanding animal behaviour and balances in nutrient supply can improve food intake and increase production (Akbar, 2018). Sheep are classified as non-selective ruminants, part of the grazer group, in terms of diet selection and feed intake (NRC 2007). However, forage intake of confined sheep depends on its nutritional value, palatability, particle size, and the physical presentation of the diet. Thus, this study aimed to evaluate the effect of forage silage and new hybrids of saccharine sorghum and corn silage in the diet on ingestive behaviour and performance of feedlot lambs.

\section{Materials and Methods}

The experiment was carried out at the sheep farming section of the Faculty of Agricultural Sciences of the Federal University of Grande Dourados (UFGD) in Dourados, Mato Grosso do Sul, Brazil (22 ${ }^{\circ} 13^{\prime} 18.54^{\prime \prime S}$, $54^{\circ} 48^{\prime} 23.09^{\prime W}$ ). Sorghum and corn were planted in the experimental field of Embrapa Agricultural West. The soil of the experimental area was classified as a dystrophic dark red Latosol with clayey texture (Santos et al., 2013), and had these characteristics, namely $\mathrm{pH} 4.6 ; 24.4 \mathrm{mg} \mathrm{dm}^{-3}$ of phosphorus resin; $8.0 \mathrm{mmol} \mathrm{dm}^{-3}$ of potassium; $42.0 \mathrm{mmol} \mathrm{dm}{ }^{-3}$ of calcium; $17.0 \mathrm{mmol} \mathrm{dm}^{-3}$ of magnesium; $82.0 \mathrm{mmol} \mathrm{dm}^{-3}$ aluminium +, hydrogen; sum of buffers of $244.0 \mathrm{mmol} \mathrm{dm}^{-3}$; cationic exchange capacity of $149.0 \mathrm{mmol} \mathrm{dm}-3$; saturation buffer of $44.9 \%$; and $30.6 \mathrm{~g} \mathrm{dm}^{3}$ of organic matter (OM). The mean temperature in the experimental period was $28.1^{\circ} \mathrm{C}$ and the accumulated precipitation was $485.4 \mathrm{~mm}$. Fertilizer $\left(8-20-20 \mathrm{~N}-\mathrm{P}_{2} \mathrm{O}_{5}-\mathrm{K}_{2} \mathrm{O}\right)$ was applied at $450 \mathrm{~kg} \mathrm{ha}^{-1}$ at planting. Nitrogen fertilization with $500 \mathrm{~kg} \mathrm{ha}^{-1}$ of ammonium sulphate and $100 \mathrm{~kg} \mathrm{ha}^{-1} \mathrm{of} \mathrm{KCl}$ was applied 30 days after plant emergence. There was $0.45 \mathrm{~m}$ between the rows and seven plants per linear meter, to achieve a total population of 155,000 plants per hectare.

Harvesting occurred when each hybrid reached the point at which the grains had a pasty consistency, which occurred between 120 and 138 days after planting. The material was harvested manually and cut with a stationary machine. It was ensiled individually in $200-\mathrm{L}$ drums and compacted manually. Mean particle sizes were 14, 10,13, and $10 \mathrm{~mm}$, evaluated according to Lammers et al. (1996) and density of 874.38, $882.81,861.47$, and $738.82 \mathrm{~kg} / \mathrm{m}^{3}$ for BD 1615 , BRS 506, BRS 511, and BRS 2223 silage, respectively.

The animals were housed individually in $2 \mathrm{~m}^{2}$ covered pens equipped with individual mobile feeding troughs and nipple drinkers. Wood shavings were used as bedding to absorb faeces and urine, and were replaced every 15 days. Prior to the experiment, the animals were tagged, weighed, treated for internal parasites (Zolvix ${ }^{\circledR}$, Elanco, Greenfield, Indiana, USA), and allowed to adapt to the facilities and diets (Table 1) for 15 days. The diets were balanced to meet the requirements (NRC, 2007) for a mean weight gain of $0.200 \mathrm{~kg} /$ animal/day using $50 \%$ roughage (silage) and $50 \%$ concentrate. To achieve similar crude protein (CP) content in the diets, two concentrates were prepared, one for corn silage with a lower CP content, and the other for the sorghum silages with a higher CP content. The concentrates were prepared from corn, soybean meal, mineral premix, limestone, urea, ammonium sulphate, vitamin premix, sulfur fluoride, and sodium lasalocid $15 \%$. The animals were weighed fortnightly to calculate the average daily gain.

Ten intact male Suffolk lambs, $2.5 \pm 0.5$ months old and weighing $21 \pm 7 \mathrm{~kg}$, were used in the experiment. Feed was provided daily at $08 \mathrm{~h} 00$ and $16 \mathrm{~h} 00$. The amount of feed offered to each lamb was recalculated every three days to achieve $5 \%$ to $10 \%$ orts. Every day, before the first meal, the orts from the previous day were collected, weighed, and sampled to obtain intakes of DM, CP, and NDF. The samples of feed and daily orts were frozen and composited as 14-day periods (one composited sample/animal/period) for subsequent nutrient analysis. Each animal was randomly assigned to one of the dietary treatments and the evaluation process was repeated three times, resulting in a total of 30 experimental evaluations in the whole experiment. Before each evaluation, animals were allowed 14 days to adapt the new diet. The dietary treatments were based on GrandSilo® forage sorghum silage (BD 1615), saccharine sorghum silage (BRS 506 and BRS 511) and corn silage (BRS 2223).

Ingestive behaviour was recorded using a scan sampling method (Morais et al., 2006) involving seven strategically placed video cameras so as not to interfere with the usual behaviour of the animals. Six cameras each captured images of two animals, and one camera was placed in the central hallway where the feeding troughs were located. The animals were monitored by observation at five-minute intervals (Carvalho et al., 2006) during three 48-hour periods for 15 days, providing 144 hours of observation. The time spent eating (animal consuming, as seizing, masticating and swallowing food), rumination (animal standing or lying and regurgitating, re-masticating and re-swallowing the food bolus), drinking water, and idling were recorded. The data were tabulated in spreadsheets suitable for behaviour trials. The ingestive behaviour variables investigated in this experiment were the times spent eating, ruminating, idling, and drinking water. Artificial illumination was used at night throughout the experiment. Consumption rate and rumination efficiency were calculated as DM, CP, and NDF intakes divided by the time spent in the various activities (Bürger et al., 2000). 
Table 1 Diets provided to lambs fed forage sorghum silage, saccharine sorghum silages and corn silage

\begin{tabular}{|c|c|c|c|c|}
\hline \multirow{2}{*}{ Ingredients, $\mathrm{g} \mathrm{kg}^{-1}$ as feed } & \multicolumn{4}{|c|}{ Treatments } \\
\hline & BD 1615 & BRS 506 & BRS 511 & BRS 2223 \\
\hline BD 1615 silage & 500.0 & & & \\
\hline BRS 506 silage & & 500.0 & & \\
\hline BRS 511 silage & & & 500.0 & \\
\hline BRS 2223 silage & & & & 500.0 \\
\hline Corn & 323.0 & 323.0 & 323.0 & 348.0 \\
\hline Soybean meal & 150.0 & 150.0 & 150.0 & 125.0 \\
\hline Mineral premix ${ }^{1}$ & 10.0 & 10.0 & 10.0 & 10.0 \\
\hline Limestone & 10.0 & 10.0 & 10.0 & 10.0 \\
\hline Urea & 4.7 & 4.7 & 4.7 & 4.7 \\
\hline Ammonium sulphate & 1.5 & 1.5 & 1.5 & 1.5 \\
\hline Vitamin premix ${ }^{2}$ & 0.5 & 0.5 & 0.5 & 0.5 \\
\hline Sulfur fluoride & 0.2 & 0.2 & 0.2 & 0.2 \\
\hline Sodium lasalocid $15 \%$ & 0.1 & 0.1 & 0.1 & 0.1 \\
\hline \multicolumn{5}{|c|}{$\begin{array}{l}{ }^{1} \text { Calcium: } 111.00 \mathrm{~g} / \mathrm{kg} \text {, cobalt: } 50.00 \mathrm{mg} / \mathrm{kg} \text {, sulphur: } 11.99 \mathrm{~g} / \mathrm{kg} \text {, iron: } 4.42 \mathrm{mg} / \mathrm{kg} \text {, phosphorus: } 72.00 \mathrm{~g} / \mathrm{kg} \text {, iodine: } 75.00 \\
\mathrm{mg} / \mathrm{kg} \text {, magnesium: } 9.00 \mathrm{~g} / \mathrm{kg} \text {, manganese: } 1550.00 \mathrm{mg} / \mathrm{kg} \text {, selenium: } 13.50 \mathrm{mg} / \mathrm{kg} \text {, sodium: } 174.00 \mathrm{~g} / \mathrm{kg} \text {, zinc: } 7.200 .00 \\
\mathrm{mg} / \mathrm{kg} \text {, fluoride: } 720.00 \mathrm{mg} / \mathrm{kg} \\
2 \text { Vitamin A: } 15000000 \mathrm{Ul} / \mathrm{kg} \text {, vitamin D3: } 2.000 .000 \mathrm{Ul} / \mathrm{kg} \text {, vitamin E: } 5500 \mathrm{Ul} / \mathrm{kg} \\
\text { BD 1615: forage sorghum, BRS } 506 \text { : saccharine sorghum, BRS } 511: \text { saccharine sorghum, BRS 2223: corn BD 1615: } \\
\text { forage sorghum, BRS 506: saccharine sorghum, BRS 511: saccharine sorghum, BRS 2223: corn }\end{array}$} \\
\hline
\end{tabular}

The experiment was conducted as an unbalanced design, with nine repetitions of BD 1615, nine repetitions of BRS 511, six repetitions of BRS 506 and six repetitions of BRS 2223. One way analysis of variable was performed using PROC MIXED of SAS (SAS Institute Inc., Cary, North Carolina, USA). Differences among the treatment means were evaluated based on Duncan's test at $P=0.05$. Principal component analyses (PCA) were performed using STATISTICA 8.2 (Cary, North Carolina, USA) to group the data of intake, feeding behaviour and average daily gain.

\section{Results}

The $\mathrm{CP}$, ether extract (EE), $\mathrm{Ca}$ and $\mathrm{P}$ levels in the diets offered to lambs were similar for all silage types. BRS 511 had the highest DM and OM content. The contents of NDF and acid detergent fibre (ADF) were lowest for BRS 2223 and highest for BD 1615, with similar levels for BRS 506 and BRS 511. The estimated total digestible nutrients (TDN) was highest for BRS 2223 (Table 2).

The greatest DMI was observed for BRS 2223 and was similar among the sorghum silages (Table 3). Crude protein intake was highest for BRS 2223 and BD 1615, with the latter also being similar to the saccharine sorghum silages. The greater DM and CP intake by the lambs fed BRS 2223 was probably because their diet contained less fibre and favoured the intake of those nutrients (NRC 2007). Consumption of NDF was greatest for BD 1615 and BRS 2223 and less for saccharine sorghum silage, with no difference between saccharine sorghum silages and BRS 2223 (Table 3). Neutral detergent fibre has an important role in DMI and feed digestibility (Pu et al., 2019). The increased consumption of NDF by animals fed BD 1615 was associated with the greater amount of NDF in their diet. 
Table 2 Chemical composition of diets provided to lambs fed forage sorghum silage, saccharine sorghum silage and corn silage

\begin{tabular}{lrrrr}
\hline \multirow{2}{*}{ Diet contents } & \multicolumn{4}{c}{ Silage treatments ${ }^{1}$} \\
\cline { 2 - 5 } & BD 1615 & BRS 506 & BRS 511 & BRS 2223 \\
\hline Dry matter $(\mathrm{g} / \mathrm{kg})$ & $339.0^{\mathrm{c}}$ & $350.6^{\mathrm{b}}$ & $364.5^{\mathrm{a}}$ & $346.0^{\mathrm{bc}}$ \\
Organic matter $(\mathrm{g} / \mathrm{kg}$ of DM) & $937.3^{\mathrm{c}}$ & $946.7^{\mathrm{b}}$ & $949.9^{\mathrm{a}}$ & $947.3^{\mathrm{b}}$ \\
Crude protein $(\mathrm{g} / \mathrm{kg}$ of DM) & 131.5 & 128.2 & 126.6 & 137.7 \\
Ether extract $(\mathrm{g} / \mathrm{kg}$ of DM) & 13.5 & 13.5 & 13.5 & 14.0 \\
Neutral detergent fibre $(\mathrm{g} / \mathrm{kg}$ of DM) & $446.1^{\mathrm{a}}$ & $410.5^{\mathrm{b}}$ & $409.8^{\mathrm{b}}$ & $361.1^{\mathrm{c}}$ \\
Acid detergent fibre $(\mathrm{g} / \mathrm{kg}$ of DM) & $201.7^{\mathrm{a}}$ & $172.6^{\mathrm{b}}$ & $175.6^{\mathrm{b}}$ & $129.7^{\mathrm{c}}$ \\
Total digestible nutrients $(\mathrm{g} / \mathrm{kg}$ of DM) & $703.2^{\mathrm{b}}$ & $690.9^{\mathrm{b}}$ & $702.5^{\mathrm{b}}$ & $746.6^{\mathrm{a}}$ \\
Calcium (g/kg of DM) & 5.37 & 5.37 & 5.37 & 5.37 \\
Phosphorus (g/kg of DM) & 2.52 & 2.52 & 2.52 & 2.52 \\
\hline
\end{tabular}

${ }^{1}$ BD 1615: forage sorghum, BRS 506: saccharine sorghum, BRS 511: saccharine sorghum, BRS 2223: corn

a, b, c Within a row values with a common superscript do not differ $(P<0.05)$

Table 3 Dry matter and nutrient intakes of lambs fed forage sorghum, saccharine sorghum and corn silages

\begin{tabular}{lcrccrr}
\hline \multirow{2}{*}{$\begin{array}{l}\text { Response } \\
\text { variable }\end{array}$} & \multicolumn{3}{c}{ Treatments $^{1}$} & \multirow{2}{*}{ SEM } & $P$-value \\
\cline { 2 - 5 } & BD 1615 & BRS 506 & BRS 511 & BRS 2223 & & \\
\hline DM (kg) & $1.04^{\mathrm{ab}}$ & $0.93^{\mathrm{b}}$ & $0.96^{\mathrm{b}}$ & $1.26^{\mathrm{a}}$ & 0.20 & 0.03 \\
$\mathrm{CP}(\mathrm{kg})$ & $0.13^{\mathrm{ab}}$ & $0.11^{\mathrm{b}}$ & $0.11^{\mathrm{b}}$ & $0.15^{\mathrm{a}}$ & 0.03 & 0.04 \\
$\mathrm{NDF}(\mathrm{kg})$ & $0.41^{\mathrm{a}}$ & $0.31^{\mathrm{b}}$ & $0.33^{\mathrm{b}}$ & $0.38^{\mathrm{ab}}$ & 0.07 & 0.04
\end{tabular}

${ }^{1}$ BD 1615: forage sorghum, BRS 506: saccharine sorghum, BRS 511: saccharine sorghum, BRS 2223: corn, DM: dry matter, CP: crude protein, NDF: neutral detergent fibre

a, b, c Within a row, values with a common superscript do not differ $(P<0.05)$

It was generally observed animals fed BRS 511 had ingestive behaviours most similar to those fed BRS 2223, and animals fed BRS 506 had ingestive behaviours that were similar to those fed BD 1615 (Table 4). The feeding and drinking times did not differ between treatments. Animals ruminated less when fed BRS 511 and BRS 2223, and consequently spent more time idling. Time spent chewing was similar for BRS 506 , BD 1615 and BRS 2223. Animals fed BD 1615 had the highest NDF intake with its larger particle size, and consequently spent most time ruminating. Time spent on rumination is proportional to the cell-wall content in the food (Ferro et al., 2018). Thus, by raising the NDF content of the diets, rumination time would be extended (Van Soest, 1994; Harper \& McNeill, 2015). Forages that are high in NDF required longer rumination owing to the need to process the increased amount of dietary fibre (Merchen \& Church, 1988; Saraiva et al., 2015). Since animals fed BRS 506 and BRS 511 had lower but similar NDF intake, it was expected that these animals would spend similar amounts of time ruminating. This expectation makes the observed difference in their rumination times difficult to explain. Orrico Junior et al. (2015) found BRS 506 silage contained more lignin (3.84\%) than BRS 511 silage (3.18\%). The higher levels of lignin in BRS 506 silage may possibly decrease the rate of passage and therefore increase rumination time. 
Table 4 Time spent on daily ingestive activities ( $\mathrm{min} /$ day) in lambs fed forage sorghum silage, saccharine sorghum silage and corn silage

\begin{tabular}{lccrrrrr}
\hline $\begin{array}{l}\text { Ingestive behaviour } \\
\text { (minutes/day) }\end{array}$ & \multicolumn{3}{c}{ Treatments $^{1}$} & & SEM & $P$-value \\
\cline { 2 - 5 } & BD 1615 & BRS 506 & BRS 511 & BRS 2223 & \\
\hline Eating time & 216.39 & 222.08 & 215.00 & 228.33 & 40.06 & 0.92 \\
Ruminating time & $341.94^{\mathrm{a}}$ & $360.42^{\mathrm{a}}$ & $262.50^{\mathrm{b}}$ & $270.00^{\mathrm{b}}$ & 62.11 & 0.01 \\
Chewing' time & $558.33^{\mathrm{a}}$ & $582.50^{\mathrm{a}}$ & $477.50^{\mathrm{b}}$ & $498.33^{\mathrm{ab}}$ & 55.06 & $<0.01$ \\
Drinking water time & 21.11 & 20.00 & 20.00 & 17.92 & 9.37 & 0.94 \\
Idle time & $853.80^{\mathrm{b}}$ & $830.83^{\mathrm{b}}$ & $935.83^{\mathrm{a}}$ & $917.08^{\mathrm{a}}$ & 55.39 & $<0.01$
\end{tabular}

${ }^{1}$ BD 1615: forage sorghum, BRS 506: saccharine sorghum, BRS 511: saccharine sorghum, BRS 2223: corn

${ }^{2}$ Chewing: ingestion + rumination

a, b, c Within a row values with a common superscript do not differ $(P<0.05)$

Rumination efficiency is important for controlling roughage use and may restrict the use of low-quality feed, which compromises animal production (Welch, 1982; Vinhas Voltolini et al., 2009; Sampaio et al., 2010). The rates at which DM, CP, and NDF were consumed did not differ between treatments $(P>0.05)$ (Table 5). Since rumination time was less and intake was greater, BRS 2223 had the highest rumination efficiency for DM, which was lowest for BRS 506 . This was probably because of the lower DM digestibility of BRS 506 silage compared with BRS 511 (Orrico Junior et al., 2015). The three treatments containing sorghum silage had similar CP rumination efficiency, all of which were lower than that observed for BRS 2223. Treatment BRS 511 had similar NDF rumination efficiency to BRS 2223 and BD 1615. The high rumination efficiency of NDF for BRS 511 was because the animals spent less time ruminating in relation to the time they spent eating. BD 1615 contained the highest level of NDF. The consequent reduction in DMI by animals fed BD 1615 may have led to the observed reduced rumination efficiency owing to its dependence on the amount of feed consumed (Silva et al., 2017). This reduced rumination efficiency cannot be made up for by extending rumination time.

Table 5 Consumption rate and rumination efficiency $(\mathrm{kg} / \mathrm{h})$ of dry matter, crude protein, and neutral detergent fibre of lambs fed forage sorghum silage, saccharine sorghum silage and corn silage

\begin{tabular}{|c|c|c|c|c|c|c|}
\hline \multirow{2}{*}{ Variables } & \multicolumn{4}{|c|}{ Treatments $^{1}$} & \multirow{2}{*}{ SEM } & \multirow{2}{*}{$P$-value } \\
\hline & BD 1615 & BRS 506 & BRS 511 & BRS 2223 & & \\
\hline \multicolumn{7}{|l|}{ Consumption rate } \\
\hline FEDM (kg DM/h) & 0.30 & 0.26 & 0.27 & 0.36 & 0.093 & 0.28 \\
\hline FECP (kg CP/h) & 0.04 & 0.03 & 0.03 & 0.04 & 0.012 & 0.33 \\
\hline FENDF (kg NDF/h) & 0.12 & 0.09 & 0.09 & 0.11 & 0.030 & 0.22 \\
\hline \multicolumn{7}{|l|}{ Rumination efficiency } \\
\hline REDM kg DM/h) & $0.19^{b c}$ & $0.16^{\mathrm{c}}$ & $0.23^{b}$ & $0.29^{\mathrm{a}}$ & 0.053 & $<0.01$ \\
\hline $\operatorname{RECP}(\mathrm{kg} \mathrm{CP} / \mathrm{h})$ & $0.02^{\mathrm{b}}$ & $0.02^{b}$ & $0.03^{b}$ & $0.04^{a}$ & 0.007 & $<0.01$ \\
\hline RENDF (kg NDF/h) & $0.07^{\mathrm{ab}}$ & $0.05^{\mathrm{b}}$ & $0.08^{\mathrm{a}}$ & $0.09^{a}$ & 0.016 & 0.01 \\
\hline
\end{tabular}

${ }^{1}$ BD 1615: forage sorghum, BRS 506: saccharine sorghum, BRS 511: saccharine sorghum, BRS 2223: corn, FEDM: feeding efficiency of dry matter, FECP: feeding efficiency of crude protein, FENDF: feeding efficiency of neutral detergent fibre, REDM: rumination efficiency of dry matter, RECP: rumination efficiency of crude protein, RENDF: rumination efficiency of neutral detergent fibre

a, b, c Within a row values with a common superscript do not differ $(P<0.05)$

The animals fed BRS 2223 had greater average daily gain, followed by BD 1615, and lambs fed BRS 506 and BRS 511 had lower average daily gains (Figure 1). Factors 1 and 2 of the PCA (Figure 2) explained 
$56.39 \%$ and $27.91 \%$ of total variance, respectively. Thus, average daily gain is indicated as being more related to DM and nutrient intake than it is to rumination efficiency. Average daily gains result from the consumption of DM and nutrients and from rumination efficiency. Animals with higher intake, such as those fed BRS 2223 and BD 1615, had better performance. However, low rumination efficiency can reduce average daily gain, as occurred with BD 1615. Lambs with lower DMI, that is, those that were fed BRS 506 and BRS 511, had reduced performance, regardless of their rumination efficiency.

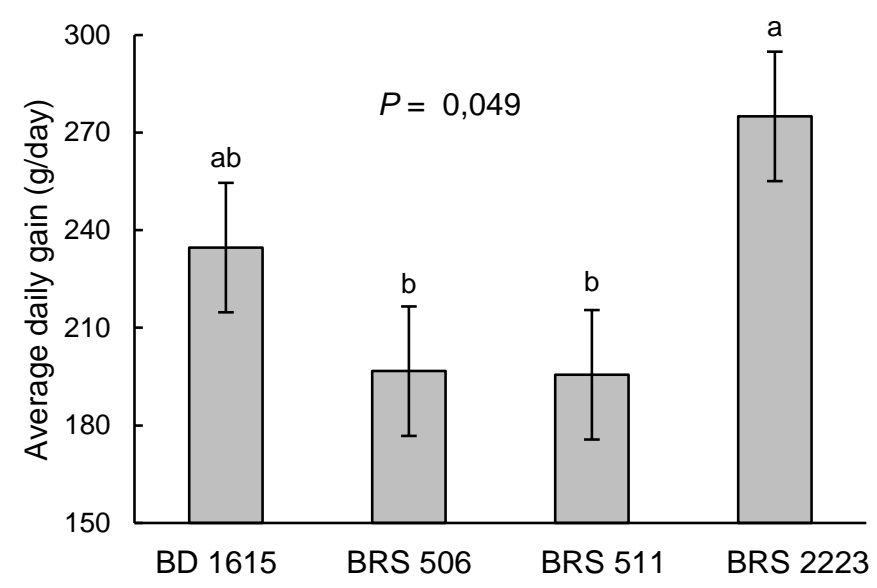

Figure 1 Average daily gain of lambs fed forage sorghum silage, saccharine sorghum silage and corn silage BD 1615: forage sorghum, BRS 506: saccharine sorghum silage, BRS 511: saccharine sorghum silage, BRS 2223: corn silage

$a, b, c$ Values with a common superscript do not differ $(P<0.05)$

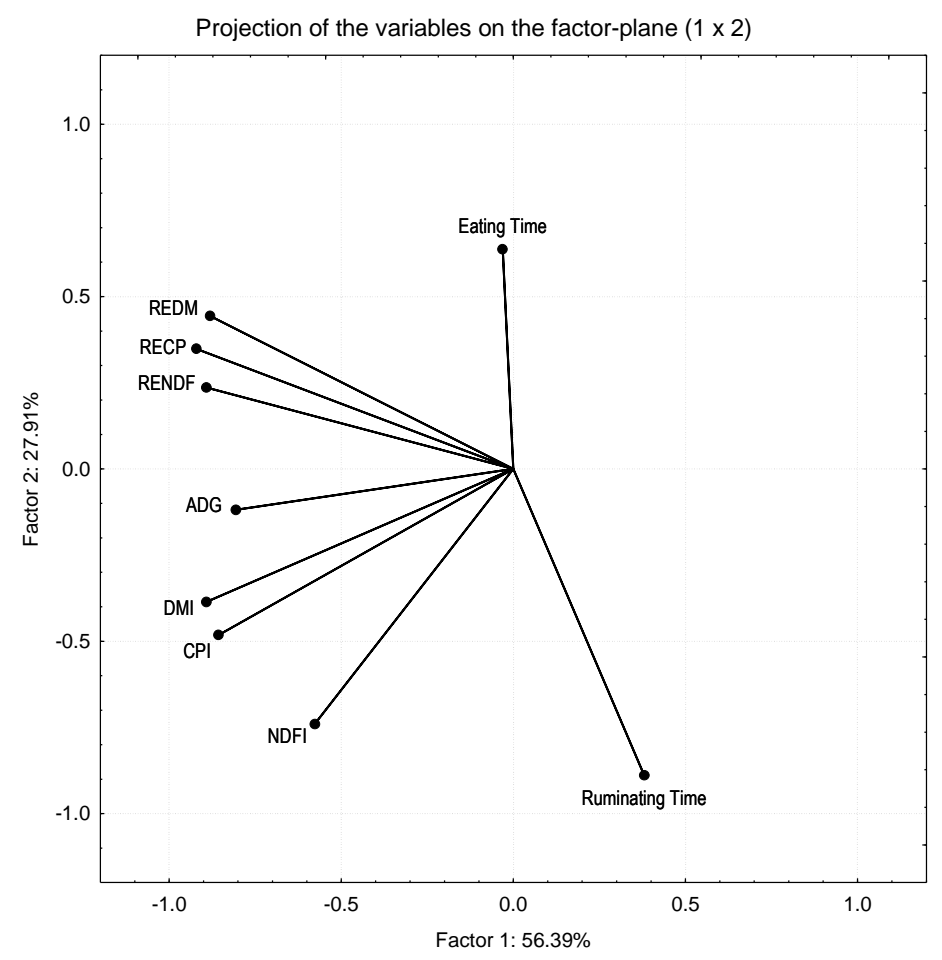

Figure 2 Principal component analysis of intake, feeding behaviour, and average daily gain of lambs fed forage sorghum silage, saccharine sorghum silage and corn silage

DMI: dry matter intake, CPI: crude protein intake, NDFI: neutral detergent fibre intake, REDM: DM rumination efficiency, RECP: CP rumination efficiency, RENDF: NDF rumination efficiency, ADG: average daily gain 


\section{Conclusion}

The new sorghum hybrids BRS 506 and BRS 511 reduced consumption and consequently animals did not perform so well as those fed BD 1615 or BRS 2223. However, BRS 506 may be an alternative for diets with a higher level of concentrate, because feeding this hybrid would result in longer rumination, and thus would help to maintain the rumen environment. BRS 511 had higher rumination efficiency and could be used in diets with another source of bulk.

\section{Acknowledgements}

Appreciation is extended to the Brazilian Agricultural and Livestock Research Corporation (EMBRAPA); Brazilian Federal Agency for Post-Graduate Education (CAPES; Brasilia, DF, Brazil); Foundation for Support to the Development of Education, Science and Technology of the State of Mato Grosso do Sul ((FUNDECT) Campo Grande, MS, Brazil), and National Research Council (CNPq; Brasilia, DF, Brazil) for the grants to the authors.

\section{Authors' Contributions}

FMVJ participated in designing the study, in the statistics and interpretation of the data and in constructive revision of the manuscript. KC, HLP, MLL and ACV participated in data collection. MAPOJ participated in designing the study. MR participated in designing the study. ABRS participated in designing the study, and data collection. TF was involved in the statistics and interpretation of the data and constructive revision of manuscript.

\section{Conflict of Interest Declaration}

The authors declare that they have no competing interests.

\section{References}

Akbar, N. 2018. Physical and metabolic constraints on feed intake in ruminants: A systematic model. J. Adv. Dairy Res. 6, 204.

Bürger, P.J., Pereira, J.C., Queiroz, A.C., Coelho da Silva, J.F., Valadares Filho, S.C., Cecon, P.R. \& Casali, A.D.P., 2000. Comportamento ingestivo em bezerros holandeses alimentados com dietas contendo diferentes níveis de concentrado. Rev. Bras. Zoot. 29, 236-242.

Carvalho, G.G.P., Pires, A.J.V., Silva, R.R., Veloso, C.M. \& Silva, H.G.O., 2006. Comportamento ingestivo de ovinos alimentados com dietas compostas de silagem de capim-elefante amonizada ou não e subprodutos agroindustriais. Rev. Bras. Zoot. 35, 1805-1812.

Ferro, M.M., Zanine, A.M., Ferreira, D.J., de Souza, A.L., Geron, L.J.V., de Castro, W.J.R., Parente, H.N., Parente, M.O.M \& Alves, G.R. 2018. Ingestion behaviour of feedlot sheep fed on bean processing residue. Int. J. Agric. Biol. 21, 164-170.

Harper, K. \& McNeill, D., 2015. The role of iNDF in the regulation of feed intake and the importance of its assessment in subtropical ruminant systems (the role of iNDF in the regulation of forage intake). Agriculture $5,778$.

Lammers, B.P., Buckmaster, D.R. \& Heinrichs, A.J., 1996. A simple method for the analysis of particle sizes of forage and total mixed rations. J. Dairy Sci. 79, 922-928.

Merchen, N. \& Church, D., 1988. Digestión, absorción y excreción en los rumiantes. CHURCH, CD EI Rumiante Fisiologia digestiva y nutrición. Cap 9.

Morais, J.B., Susin, I., Pires, A.V., Mendes, C.Q., Oliveira Junior, R.C. \& Packer, I.U., 2006. Comportamento ingestivo de ovinos e digestibilidade aparente dos nutrientes de dietas contendo casca de soja. Pesqui. Agropecu. Bras. 41, 1157-1164.

NRC (National Research Council), 2007. Nutrient requirements of small ruminants: Sheep, goats cervids, and New World camelids, 7th ed. National Academy Press, Washington, DC, 292

Orrico Junior, M.A.P., Retore, M., Manarelli, D.M., Souza, F.B., Ledesma, L.L.M. \& Orrico, A.C.A., 2015. Forage potential and silage quality of four varieties of saccharine sorghum. Pesqui. Agropecu. Bras. 50, 1201-1207.

Pu, X., Guo, X., Jiang, C., Liu, J., Zhang, X., Zhang, S., Cheng, L. \& Shan, A. 2019. Effects of dietary NFC/NDF on rumen microbiomes of Karakul sheep based on three generations of full-length amplifiers sequencing. BioRxiv. 10.1101/729780.

Sampaio, C.B., Detmann, E., Paulino, M.F., Valadares Filho, S.C., de Souza, M.A., Lazzarini, I., Rodrigues Paulino, P.V. \& de Queiroz, A.C., 2010. Intake and digestibility in cattle fed low-quality tropical forage and supplemented with nitrogenous compounds. Trop. Anim. Health Prod. 42, 1471-1479.

Santos, H.G., Jacomine, P.K.T., Anjos, L.H.C., Oliveira, V.A., Lumbreras, J.F., Coelho, M.R., Almeida, J.A., Cunha, T.J.F. \& Oliveira, J.B., 2013 Sistema brasileiro de classificação de solos. 3rd ed. Embrapa, Brasília, Brazil.

Saraiva, C.A.S., Gonzaga Neto, S., Henriques, L.T., Queiroz, M.F.S., Saraiva, E.P., Albuquerque, R.P.d.F., Fonseca, V.d.F.C. \& Nascimento, G.V.d., 2015. Forage cactus associated with different fiber sources for lactating Sindhi cows: production and composition of milk and ingestive behavior. Rev. Bras. Zoot. 44, 60-66.

da Silva, P.C.G., Ítavo, C.B.F., Ítavo, L.C.V., Morais, M.G., da Silva, J.A., Heimbach, N.S., de Melo, G.K.A. \& da Costa, M.C.M., 2017. Protein-energy supplementation for lambs: Feed intake, ingestive behavior, rumen parameters and nutrient digestibility. Semina, Ciênc. Agrár. 38.

Van Soest, P.J., 1994. Nutritional ecology of the ruminant. Cornell University Press. Ithaca, New York, USA.

Verma, R., Kumar, R. \& Nath, A. 2018. Drought resistance mechanism and adaptation to water stress in sorghum (Sorghum bicolor (L.) Moench). IntER. J. Bio-res. Stress Manag. 9,167-172. 
Vinhas Voltolini, T., Nilton Moreira, J., Maia Nogueira, D., Ribeiro Pereira, L.G., Romero Bulhões Azevedo, S. \& Costa Lins, P.R., 2009. Fontes protéicas no suplemento concentrado de ovinos em pastejo. Acta Sci. Anim. Sci. 31.

Welch, J., 1982. Rumination, particle size and passage from the rumen. J. Anim. Sci. 54, 885-894. 